\title{
SISTEM INFORMASI MANAJEMEN PRAKTEK KERJA LAPANGAN BERBASIS WEBSITE (STUDI KASUS PROGRAM STUDI SISTEM INFORMASI UNIVERSITAS DHYANA PURA BALI)
}

\author{
I Gede Ngurah Wira Pratama ${ }^{1)}$ I.G.N Anom Cahyadi Putra ${ }^{2)}$ Aulia Iefan Datya ${ }^{3)}$ \\ Program Studi Sistem Informasi 1) 2) 3) \\ Fakultas Ilmu Kesehatan Sains dan Teknologi, Universitas Dhayana Pura, Badung, Bali 1) 2) 3) \\ teplusading@gmail.com ${ }^{1)}$ anomcahyadi@undhirabali.ac.id ${ }^{2}$ iefandatya@undhirabali.ac.id ${ }^{3)}$
}

\begin{abstract}
Practical work is one of the systematic and synchronous implementation of the campus education program with the skills acquistion program obtanied through direct work activities in the workforce to achieve a certain level of expertise. The process of registration and reporting the implementation of practical work in the information systems studi program is still done manually. Based on this the authors make a practical work information system management based on the study program of the unversity information system Dhyana Pura. For the creation of website applications built using the programming language HTLM, PHP and MySql database. For system design using DFD(data flow diagram). From the result of making that with existence of information system of practical work management is expected to help student of study program of information system.
\end{abstract}

Key Word : Information System Management, Practical Work, Website

\begin{abstract}
ABSTRAK
Praktek Kerja Lapangan (PKL) merupakan salah satu bentuk implementasi secara sistematis dan sinkron antara program pendidikan di kampus dengan program penguasaan keahlian yang diperoleh melalui kegiatan kerja secara langsung didunia kerja untuk mencapai tingkat keahlian tertentu. Proses pendaftaran dan pelaporan pelaksanaan Praktek Kerja Lapangan(PKL) di Prodi Sistem Informasi masih dilakukan secara manual. Berdasarkan hal tersebut penulis membuat Sistem Informasi Manajemen Praktek Kerja Lapangan Berbasis Website Pada Program Studi Sistem Informasi Universitas Dhyanapura Bali. Untuk pembuatan aplikasi website dibangun dengan menggunakan Bahasa pemrograman HTML, PHP dan database MySOL. Untuk perancangan sistem menggunakan DFD (Data Flow Diagram). Dari hasil pembuatan tersebut, bahwa dengan adanya sistem informasi manajemen praktek kerja lapangan ini diharapkan dapat membantu mahasiswa program studi sistem informasi dalam pelaksanaan peraktek kerja lapangan. Kata Kunci : Sistem Informasi Manajemen, Praktek Kerja Lapangan, Website.
\end{abstract}




\section{PENDAHULUAN}

Perkembangan sistem informasi dari waktu ke waktu mengalami perubahan yang sangat signifikan seiring dengan perkembangan teknologi informasi. Perubahan dan perkembangan teknologi dan sistem informasi yang maju semakin banyak dibutuhkan dalam membantu menyelesaikan pekerjaan manusia di berbagai bidang. Praktek Kerja Lapangan (PKL) merupakan salah satu bentuk implementasi secara sistematis dan sinkron antara program pendidikan di sekolah/kampus dengan program penguasaan keahlian yang diperoleh melalui kegiatan kerja secara langsung didunia kerja untuk mencapai tingkat keahlian tertentu. Selain itu PKL merupakan salah satu kegiatan akademik yang wajib diikuti oleh seluruh siswa/mahasiswa pada program studi tertentu. Tempat PKL adalah perusahaan atau instansi yang bekerjasama dengan sekolah/kampus, dengan adanya PKL perusahaan/instansi memperoh keuntungan diantaranya adalah perusahaan/instansi akan mendapat bantuan tenaga dari siswa/mahasiswa yang melakukan praktek secara cuma-cuma, adanya kerjasama/hubungan baik antara sekolah/kampus dengan perusahaan/instansi sehingga perusahaan/instansi tersebut dikenal oleh kalangan akademis dan dunia pendidikan, adanya orang yang mengaudit perusahaan/ instansi tanpa mengeluarkan biaya dengan adanya laporan-laporan magang yang diberikan kepada perusahaan/instansi akan mendapatkan calon karyawan dari peserta magang tanpa harus melalui seleksi.

Dalam dunia pendidikan, Praktek kerja Lapangan yang disebut PKL, merupakan kewajiban bagi mahasiswa yang memang mengambil mata kuliah tersebut, tidak terkecuali pada Jurusan S-1 Sistem Informasi Universitas Dhyana pura Bali. Praktek kerja lapangan dilaksanakan oleh mahasiswa semester 5 yang di lakukan selama 3 bulan, namun kerap dalam pelaksanaannya masih terjadi kekurangan informasi bagi mahasiswa. Banyak diantaranya yang belum mengetahui dimana mendapatkan infromasi tentang praktek kerja lapangan, apa langkah-langkah untuk mencari tempat praktek kerja lapanangan, dan perusahaan-perusahaa yang layak di masuki. Karena selain universitas, sekolah-sekolah banyak yang melakukan PKL (Praktek Kerja Lapangan) dalam perusahaan yang sama. Salah satu tujuan praktek kerja lapangan adalah untuk mengetahui jenis-jenis pelayanan terhadap pelanggan yang diberikan oleh perusahaan.
Memperkenalkan mahasiswa pada situasi di dunia kerja yang sesungguhnya, dimana pada saat menjalankan praktek kerja lapangan mahasiswa dapat melihan langsung dan mampu menyesuaikan diri dalam dunia pekerjaan nantinya setelah menyelesaikan perkuliahan.

Saat ini proses pendaftaran dan pelaporan pelaksanaan PKL di Prodi Sistem Informasi masih dilakukan secara manual. Proses manual inilah yang menjadi kendala bagi Ketua Prodi Sistem Informasi untuk melakukan pemilihan/penugasan dosen pendamping PKL serta monitoring proses PKL. Disamping itu proses manual juga menjadi kendala lambatnya proses pembuatan laporan hasil PKL oleh bagian administrasi Prodi. Bagian administrasi prodi juga seringkali tidak dapat melakukan pendataan secara lengkap dikarenakan dokumen fisik persyaratan PKL terselip atau hilang. Mahasiswa juga harus selalu menanyakan ke prodi mengenai data dosen yang akan membimbing PKL kelompok mereka

Dengan permasalahan diatas maka penulis mencoba membuat sistem yang membantu mahasiswa terkhususnya mahasiswa program studi Sistem Informasi untuk mmendapatkan informasi dalam pekalsanaan praktek kerja lapangan sehingga penulis membuat sistem untuk ini dengan mengangkat judul Sistem Informasi Manajemen Praktek Kerja Lapangan Berbasis Website (Studi Kasus Progrm Studi Sistem Informasi Universitas Dhyana Pura Bali). Adapun masalah dari penelitian ini adalah "bagaimana membangun sistem informasi manajemen praktek kerja lapangan berbasis website"yang dapat mem-bantu mahasiswa dalam pelaksanaan praktek kerja lapangan. Berdasarkan uraian per-masalahan di atas, maka penulis membatasi masalah-masalah yang dikaji dalam penelitian ini, yaitu: Sistem ini akan difokuskan pada aplikasi berbasis website. Sistem ini dibangun dengan PHP dan MySQL. Sistem ini hanya digunakan oleh program studi Sistem Informasi Universitas Dhyana pura Bali. Tujuan dari penyusunan ini adalah untuk:

Untuk memberikan informasi dan tata cara dalam pelaksanaan praktek kerja lapangan. Dapat mempermudah mahasiswa untuk mendapatkan informasi yang jelas, akurat, relevan dan benar tentang praktek kerja lapangan yang akan mereka lakukan. Menyajikan Sistem Informasi Praktek Kerja Lapangan Pada Jurusan Sistem Informasi Universitas Dhyana 
pura Bali. Beberapa manfaat yang diperoleh dari sistem berikut :

Membantu peneliti dalam menerapkan pengetahuan dan keterampilan dengan langsung merancang aplikasi sehingga dapat merasakan dan menghayati apakah ilmu pengetahuan yang diperoleh selama ini dapat dipergunakan sebaik mungkin. Membantu pengguna dalam memudahkan dalam mendapatkan dan melaksanakan praktek kerja lapangan. Adanya penelitian ini di harapkan untuk mempermudah para mahasiswa dalam memperoleh informasi praktek kerja lapangan secara efektif dari segi waktu dan biaya

\section{TINJAUAN PUSTAKA}

\section{Praktek Kerja Lapangan (PKL)}

Kerja praktek merupakan salah satu matakuliah wajib bagi seluruh mahasiswa Jurusan Sistem Informasi, dengan beban 3 SKS. Untuk melengkapi nilai akademik yang diperlukan sebagai alat kontrol bagi prodi tentang perkembangan hasil belajar mahasiswa. Keberadaan kerja praktek dimaksudkan untuk melatih mahasiswa dalam menerapkan metode keilmuan Sistem Informasi dalam mengidentifikasi masalah sampai penyusunan alternatif solusi masalah yang tertuang dalam laporan ilmiah/penelitian kerja praktek. Kerja praktek diharapkan dapat menjadi wahana latihan bagi mahasiswa untuk memasuki dunia kerja, sehingga diharapkan dapat menambah wawasan serta keahlian dalam bidang penerapan ilmu sistem informasi salah satu sasaran kerja praktek adalah mengetahui bagaimana suatu projek yang menyangkut aspek suatu sistem informasi dijalankan, mulai dari studi kelayakan, menganalisis sistem, merancang sistem, mengimplementasikan serta merawatnya. Projek di sini bisa berarti sebagai projekriil atau simulasi projek, dimana tidak tertutup kemungkinan bahwa permasalahan yang diperoleh selama Kerja Praktek. Sehingga mahasiswa dapat memberikan sumbangsih guna memperbaiki proses bisnis maupun layanan dalam pada perusahaan tempat PKL pada khususnya dan masyarakat pada umumnya. PKL dilaksanakan secara kelompok dengan jumlah anggota maksimal 5 orang. Untuk membantu kelancaran PKL maka setiap kelompok akan didampingi oleh seorang dosen pendamping yang ditunjuk oleh prodi. Dosen pendamping ini juga bertanggung jawab untuk memberikan penilaian terhadap hasil PKL. Hal ini dapat dilakukan bila tingkat signifikansi permasalahan tersebut dipandang layak, oleh sebab itu perlu dikaitkan dalam melaksanakan Kerja Praktek antara lain mencermati dan mengidentifikasi (observe \& identify), analisis(analysis), mendesain (design), atau memprogram(code/program) semua aspek sistem informasi yang muncul, sehingga kemungkinan bisa menemukan satu atau lebih permasalahan yang layak untuk dilanjutkan menjadi Tugas Akhir. Ruang lingkup Kerja Praktek Program Studi Sistem Informasi bisa meliputi Sistem Pengolahan Data, Sistem Informasi Manajemen, Sistem Pendukung Keputusan, Sistem Pakar, Multimedia, Sistem Jaringan Komputer, Internet, Sistem Mobile, Sistem Operasi dan Pemrograman Website.

\section{PHP (Personal Home Page)}

Hypertext Preprocessor (PHP) yaitu bahasa pemograman web server-side yang bersifat open source". PHP merupakan script yang terintegrasi dengan HTML dan berada pada server (server side HTML embedded scripting). PHP adalah script yang digunakan untuk membuat halaman website yang dinamis. Dinamis berarti halaman yang akan ditampilkan dibuat saat halaman itu diminta oleh client. Mekanisme ini menyebabkan informasi yang diterima client selalu yang terbaru. Semua script PHP dieksekusi pada server di mana script tersebut dijalankan. (Anhar 2010:3).

\section{MySQL}

MySQL adalah sebuah perangkat lunak sistem manajemen basis data SQL ( bahasa inggris: database management system ) atau DBMS yang multithread, multi-user, dengan sekitar 6 juta instalasi di seluruh dunia. MySQL AB membuat MySQL tersedia sebagai perangkat lunak gratis di bawah lisensi GNU General Public License (GPL), tetapi mereka juga menjual di bawah lisensi komersial untuk kasus-kasus di mana penggunaanya tidak cocok dengan penggunaan GPL. Tidak sama dengan proyek-proyek seperti Apache, di mana perangkat lunak dikembangkan oleh komunitas umum, dan hak cipta untuk kode sumber dimiliki oleh penulisnya masing-masing, MySQL dimiliki dan disponsori oleh sebuah perusahaan komersial Swedia MySQL AB, di mana memegang hak cipta hamper atas semua kode sumbernya. Kedua orang Swedia dan satu orang Finlandia yang mendirikan MySQL AB adalah : David Axmark, Allan Larsson, dan Michael "Monty" Widenius. 


\section{Pengertian MySQL}

MySQL adalah salah satu database manajemen sistem (DBMS) dari sekian banyak DBMS seperti Oracle, MS SQL, Postgre SQL, dan lainnya". Dimana MySQL dalam operasi client-server melibatkan server daemon MySQL disisi server dan berbagai macam program serta library yang berjalan besar. SQL singkatan dari Structure Query Language dan sering disebut Sequel saja. SQL mulai dikembangkan tahun 70-an di laboratorium IBM, Stan Jose, California. Untuk mengakses sebuah file database, salah satu server database yang kecil dan mudah digunakan namun memiliki kehandalan dan performa tinggi. (Anhar 2010:45).

\section{Data flow diagram (DFD)}

DFD (Data Flow Diagram) sering digunakan untuk menggambarkan suatu sistem yang telah ada atau sistem baru yang akan dikembangkan secara logika tanpa mem-pertimbangkan lingkungan fisik dimana data tersebut mengalir (misalnya lewat telepon, surat dan sebagainya) atau lingkungan fisik dimana data tersebut akan disimpan (misalnya file kartu, microfiche, hard disk, tape, diskette dan lain sebagainya). DFD merupakan alat yang digunakan pada metodologi pengembangan sistem yang terstruktur (structured analysis and design). (Jogiyanto, 2005)

\section{Entity Relationship Diagram (ERD)}

Diagram hubungan entitas atau yang lebih dikenal dengan sebutan E-R

diagram (ERD), adalah notasi grafik dari sebuah model data atau sebuah model jaringan yang menjelaskan tentang data yang tersimpan (storage data) dalam sistem secara abstrak. Diagram hubungan entitas tidak menyatakan bagaimana memanfaatkan data, membuat data, mengubah data dan menghapus data. (Ladjamudin, 2005)

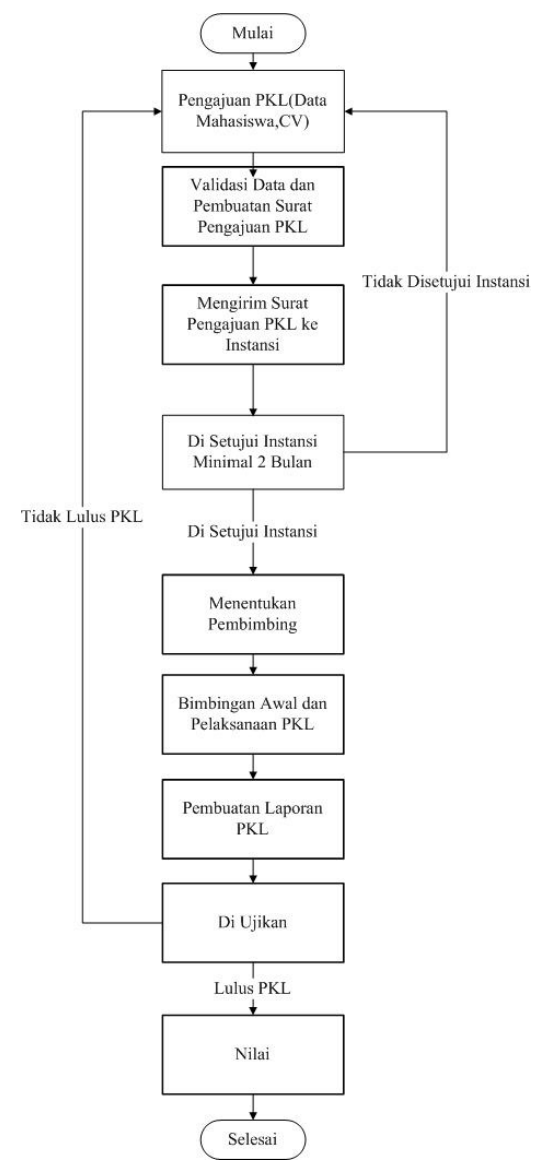

Gambar 1. ALUR PKL 


\section{Sistem Informasi Manajemen}

Suatu sistem informasi manajemen adalah Kumpulan dari manusia dan sumber daya modal di dalam suatu organisasi yang bertanggung jawab mengumpulkan dan mengolah data untuk mengahasilkan informasi yang berguna untuk semua tingkatan manajemen di dalam kegiatan perencanaan dan pengendalian". (Jogiyanto, 2005,14).

\section{HTML (HyperText Markup Language)}

Hypertext Markup Language (HTML) adalah sekumpulan simbol-simbol atau tag-tag yang dituliskan dalam sebuah file yang digunakan untuk menampilkan halaman pada web browser". Bermula dari sebuah bahasa yang sebelumnya banyak digunakan di dunia penerbitan dan percetakan yang disebut dengan SGML (Standard Generalized Markup

\section{Pengertian Database}

Database adalah sekumpulan tabel-tabel yang berisi data dan merupakan kumpulan dari field atau kolom. Struktur file yang menyusun sebuah database adalah Data Record dan Field. (Menurut Anhar 2010:45)

\section{Adobe Dreamweaver}

Dreamweaver merupakan aplikasi yang digunakan sebagai HTML editor professional untuk mendesain web secara virtual". Aplikasi ini juga yang biasa dikenal dengan istilah WYSIWYG (What You See Is What You Get), yang intinya adalah Anda tidak harus berurusan dengan tag-tag HTML untuk membuat sebuah site dan dapat melihat hasil desainya secara langsung. Dengan kemampuan fasilitas yang optimal dalam jendela design akan memberikan kemampuan untuk mendesain web meskipun untuk para web desainer pemula sekalipun. Kemampuan Dreamweaver untuk berinteraksi dengan beberapa bahasa pemrograman seperti PHP, ASP, JavaScript, dan yang lainnya juga memberikan fasilitas maksimal kepada desainer web dengan menyertakan bahasa pemrograman web di dalamnya. (Madcoms 2010:2)

\section{METODELOGI PENELITIAN \\ Lokasi Penelitian}

Penelitan di laksanakan di Universitas Dhyana Pura Bali yang berlokasi di Jalan Tegaljaya Dalung Kuta Utara Badung Bali. Universitas Dhyana Pura Bali merupakan perubahan bentuk dari sekolah tinggi ilmu manajemen
Language), HTML adalah sebuah standar yang digunakan secara luas untuk menampilkan halaman web. HTML saat ini merupakan standar internet yang didefinisikan dan dikendalikan penggunaannya oleh World Wide Web Consortium (W3C). HTML pertama kali dibuat oleh kolaborasi Caillau TIM dengan Berners-Lee Robert ketika mereka bekerja di CERN, sebuah lembaga penelitian fisika energi tinggi di Jenewa-Swiss pada tahun 1989. (Anhar 2010:40)

\section{Bagan Alir (Flowchart)}

Bagan alir (flowchart) adalah bagan (chart) yang menunjukkan alir (flow)

di dalam program atau prosedur sistem secara logika. Bagan alir digunakan terutama untuk alat bantu komunikasi dan untuk dokumentasi. (Jogiyanto, 2005).

dhyana pura yang diselenggarakan oleh Yayasan Dhyana Pura pada tahun 2011 sesuai dengan SK MENTERI PENDIDIKAN NASIONAL REPUBLIK INDONESIA NO.142/E/0/2011 TERTANGGAL 7 JULI 2011. Undhira Bali mempunya dua Fakultas yaitu Fakultas Ekonomi dan Humaniora (FEH) dan Fakultas Ilmu Kesehatan, Sains dan Teknologi (FIKST). Program Studi (Prodi) pada FEH antara lain Prodi Manajemen, Prodi Pendidikan Anak Usia Dini (PAUD), Prodi Pendidikan Dan Kesehatan Keluarga, Prodi Sastra Inggris, Diploma Manajemen Pemasaran dan Prodi Psikologi. FIKST memiliki 7 program studi yaitu Prodi Teknik Informatika, Prodi Sistem Informasi, Prodi Ilmu Kesehatan Masyarakat, Prodi Fisioterapi, Prodi Perekam dan Informasi kesehatan dan Prodi Biologi

\section{Tahapan-Tahapan Penelitian}

Dalam perancangan sistem ini penulis menggunakan metode Waterfall. Metode Waterfall adalah metode yang menyarankan sebuah pendekatan yang sistematis dan sekuensial (berurutan) melalui tahapan-tahapan yang ada pada SDLC (Software Development Life Cycle) untuk membangun sebuah perangkat lunak. SDLC adalah sebuah siklus pengembangan perangkat lunak yang terdiri dari beberapa tahapan.Tahapan-tahapan dalam SDLC meliputi requirements (analisis kebutuhan), analysis (analisis sistem), design (perancangan), coding / implementation (implementasi), testing (pengujian), dan maintenance (perawatan). 


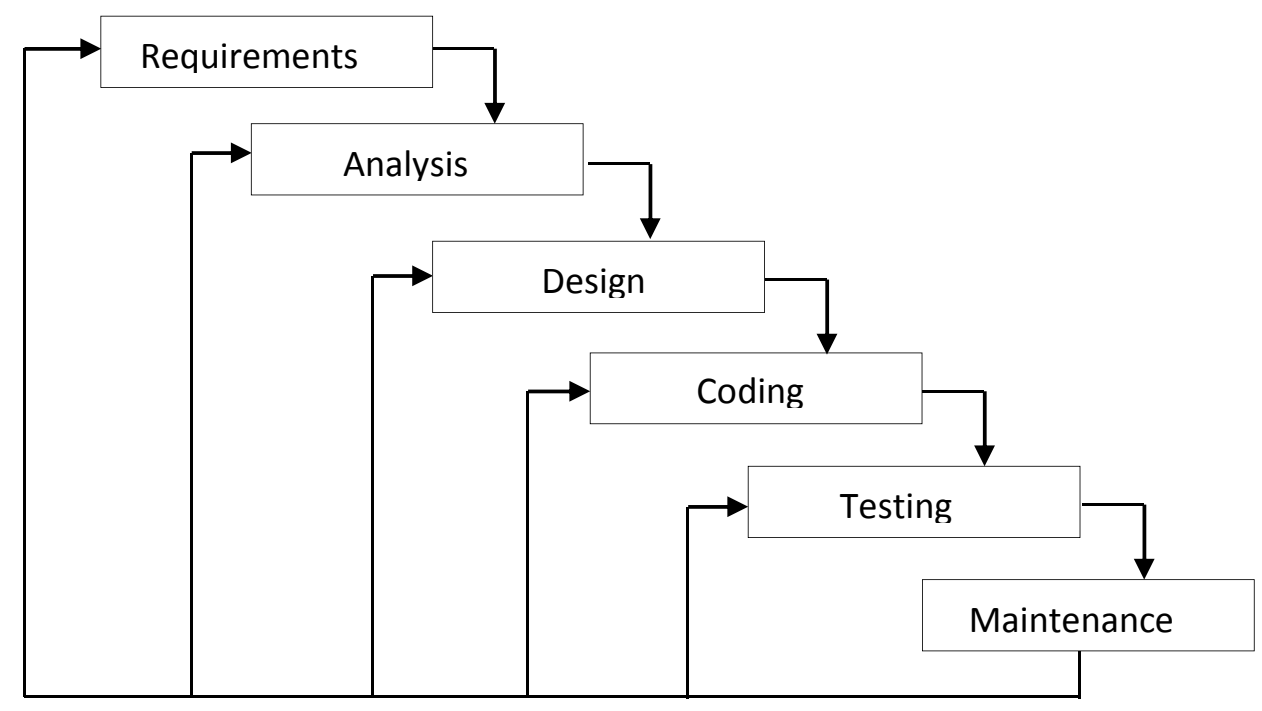

Gambar 2. Metode Waterfall

\section{Requirements (Pengumpulan Data)}

Metode Waterfall diawali dengan tahap analisis kebutuhan, tahap ini didefinisikan sebagai sebuah tahap yang menghasilkan sebuah kondisi yang diperlukan oleh pengguna untuk menyelesaikan permasalahan ataupun mencapai sebuah tujuan. Tahap ini bertujuan untuk mengumpulkan kebutuhan-kebutuhan pengguna dan kemudian mentransformasikan kedalam sebuah deskripsi yang jelas dan lengkap. Pada tahap ini penulis melakukan wawancara secara langsung kepada kepala program studi sistem informasi universitas dhyana pura Bali.Adapun teknik pengumpulan data yang digunakan adalah sebagai berikut:

\section{Analysis (Analisis Sistem)}

Tahapan kedua adalah tahap analisis sistem yang bertujuan untuk menjabarkan segala sesuatu yang nantinya akan ditangani oleh perangkat lunak. Tahapan ini adalah tahapan dimana pemodelan merupakan sebuah representasi dari object di dunia nyata. Untuk memahami sifat perangkat lunak yang akan dibangun, analis harus memahami domain informasi, dan tingkah laku yang diperlukan. Pada tahap analis, penulis melakukan analisis terhadap permasalahan yang dihadapi oleh

\section{Coding/Implementation (implementasi)}

Tahap implementasi adalah tahap yang mengkonversi apa yang telah dirancang sebelumnya kedalam sebuah bahasa yang dimengerti komputer. Kemudian komputer mahasiswa yang kesulitan untuk mendapatkan informasi tentang pelaksanaan praktek kerja lapangan, sehingga nantinya akan dijadikan landasan dalam proses perancangan perangkat lunak. Karena metode perancangan yang digunakan penulis merupakan metode perancangan terstruktur.

\section{Design System(Perancangan Sistem)}

Tahap ketiga adalah tahap peran-cangan perangkat lunak yang merupakan pro-ses multi langkah dan berfokus pada beberapa atribut perangkat lunak yang berbeda yaitu struktur data, arsitektur perangkat lunak, dan detil algoritma. Proses ini menerjemahkan kebutuhan kedalam sebuah model perangkat lunak yang dapat diperkirakan kualitasnya sebelum dimulainya tahap implementasi. Pada tahap ini penulis melakukan perancangan dari desain sistem sebelumnya kedalam bentuk desain yang akan diimplementasikan pada proses implementasi/coding. Perancangan berupa konseptual database, struktur table, design interface (perancangan antar muka perangkat lunak) dan lainnya. Berdasarkan hasil dari desain sistem, maka tahap selajutnya adalah perancangan sistem yang meliputi beberapa .bagian, antara lain:

akan menjalankan fungsi-fungsi yang telah didefinisikan sehingga mampu memberikan layanan-layanan kepada penggunanya. Pada tahap ini penulis menterjemahkan desain yang sudah dibuat sebelumnya kedalam bentuk 
perangkat lunak. Disini penulis merancang database, membuat interface dan menghubungkan database dengan program/interface dengan kode pemrograman.

\section{Testing (pengujian)}

Tahap selanjutnya adalah tahap pengujian.Terdapat dua metode pengujian perangkat lunak yang umum digunakan, yaitu metode black-box dan white-box.Pengujian dengan metode black-box merupakan pe-ngujian yang menekankan pada fung-sionalitas dari sebuah perangkat lunak tanpa mengetahui bagaimana struktur didalam perangkat lunak tersebut. Sebuah perangkat lunak yang diuji menggunakan metode black-box dikatakan berhasil jika fungsi-fungsi yang ada telah memenuhi spesifikasi kebutuhan yang telah dibuat sebelumnya. Sedangkan metode white-box menguji struktur internal perangkat lunak dengan melakukan pengujian pada algoritma yang digunakan oleh perangkat lunak.

Kemudian pada tahap pengujian penulis menggunakan dua metode pengujian, yaitu metode black-box dan metode white-box. Pada saat melakukan pengujian dengan metode black-box, penulis melakukan pengujian fungsional program dengan cara memberikan

\section{Implementasi \\ Implementasi Antar Muka}

Implementasi antar muka dilakukan dengan membuat antar muka pada masing - masing halaman. Setiap halaman aka dibuat dari sebuah file yang berektensi php. File file tersebut selanjutnya dapat di akses dan menjadi penghubung antar pengguna dengan system.

\section{Implementasi Antar Muka Admin}

form Login admin, dimana admin akan diminta memasukan username dan password untuk masuk ke menu utama sistem. Tampilan utama setelah login admin. Akan tampil secara langsung halaman dimana admin bisa melakukan maintenance data atau mengelolala sistem. Pada dashboard akan tampil informasi login admin dan ada beberapa menu pilihan yang terdapat pada halaman utama admin tersebut. Tampilan halaman dosen dimana terdapat beberapa button yang dapat admin proses yaitu Kembali, Tambah, Edit, dan Hapus. halaman edit data dosen adalah tampilan dimana admin melakukan proses edit data dosen dengan mengedit data dosen yang telah dilampirkan oleh system, yaitu NIP, Password, Nama User, Alamat, Telepon, J.K (Jenis Kelamin), Akses. tambah data dosen adalah tampilan dimana admin melakukan dokter ahli gizi untuk mencoba perangkat lunak yang telah dibuat, sehingga penulis bisa mendapatkan umpan balik untuk mengetahui apakah perangkat lunak yang telah dibuat sudah memenuhi kebutuhan pengguna dan apakah perangkat lunak sudah benar-benar bekerja dengan baik.

\section{Maintenance (perawatan)}

Tahap akhir dari metode Waterfall adalah tahap perawatan.Tahap ini dapat diartikan sebagai tahap penggunaan perangkat lunak yang disertai dengan perawatan dan perbaikan. Perawatan dan perbaikan suatu perangkat lunak diperlukan, termasuk didalamnya adalah pengembangan, karena dalam prakteknya ketika perangkat lunak tersebut digunakan terkadang masih terdapat kekurangan ataupun penambahan fitur-fitur baru yang dirasa perlu. Tahap terakhir yang akan penulis lakukan dalam pengembangan perangkat lunak ini adalah proses maintenance (perawatan). Pada tahap ini penulis akan melakukan pengembangan terhadap perangkat lunak yang sudah dibuat, guna menutupi kekurangan dari perangkat lunak jika nantinya ditemukan dan untuk meningkatkan kualitas perangkat lunak yang dibuat.

proses tambah data dosen dengan menambahkan data dosen yang digunakan dosen untuk melakukan akses login pada system. Dan menambahkan beberapa biodata serta informasi dosen. tampilan halaman dosen dimana terdapat beberapa button yang dapat admin proses yaitu Kembali, Tambah, Edit, dan Hapus. halaman edit data dosen adalah tampilan dimana admin melakukan proses edit data dosen dengan mengedit data dosen yang telah dilampirkan oleh system, yaitu NIP, Password, Nama User, Alamat, Telepon, J.K (Jenis Kelamin), Akses. tambah data dosen adalah tampilan dimana admin melakukan proses tambah data dosen dengan menambahkan data dosen yang digunakan dosen untuk melakukan akses login pada system. Dan menambahkan beberapa biodata serta informasi dosen. Halaman mahasiswa dimana terdapat beberapa button yang dapat admin proses yaitu Kembali, Tambah, Edit, dan Hapus. Halaman edit data mahasiswa adalah tampilan dimana admin melakukan proses edit data mahasiswa dengan mengedit data mahasiswa yang telah dilampirkan oleh sistem, yaitu NIM, Nama Mahasiswa, Password, Semester, dan J.K (Jenis Kelamin). Tambah data mahasiswa adalah tampilan dimana admin melakukan proses tambah data 
mahasiswa dengan menambahkan data mahasiswa yang digunakan mahasiswa untuk melakukan akses login pada system. Dan menambahkan beberapa biodata serta informasi mahasiswa. Tampilan halaman form nilai perusahaan dimana admin dapat memberikan nilai pada perusahaan tersebut. tambah nilai perusahaan adalah tampilan dimana admin melakukan proses tambah data nilai mahasiswa dengan memberikan nilai kepada mahasiswa pkl sesuai dengan kode pkl milik mahasiswa.

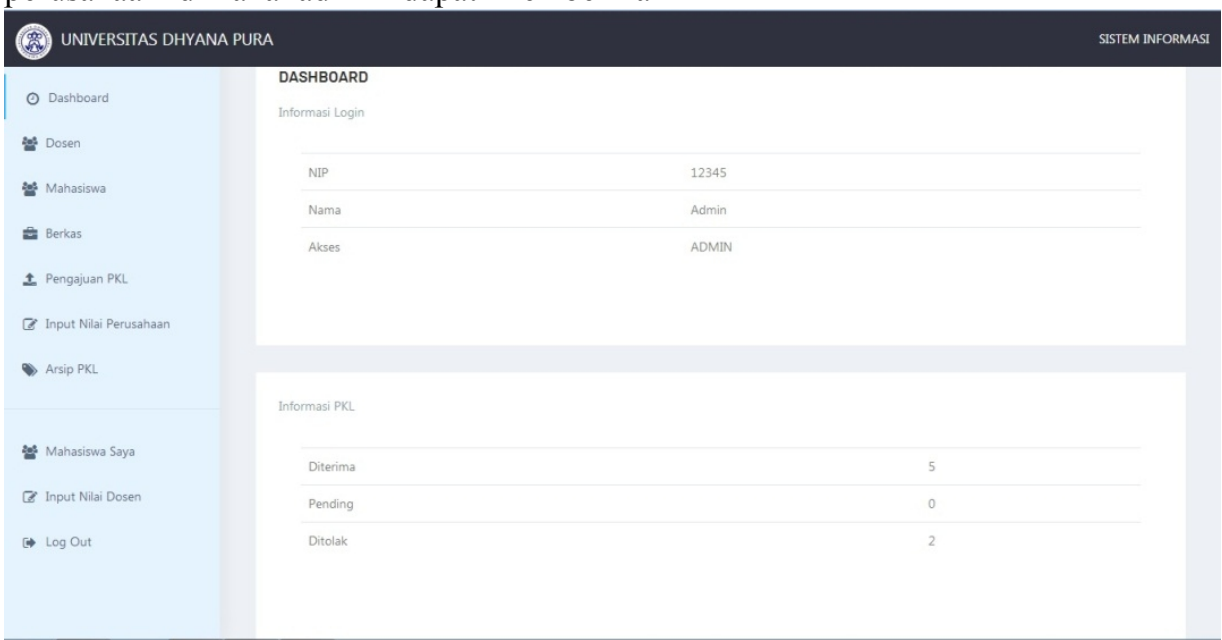

Gambar 3. Menu Utama Admin

\section{Antar Muka Halaman Dashboard Dosen}

Sebelum Masuk ke halaman dashboard dosen langkah pertama adalah melakukan login sebagai dosen. Tampilan login dosen sama dengan tampilan login admin di atas. Setelah melakukan proses login sebagai dosen maka akan tampil halaman dashboard dosen yang didalamnya terdapat beberapa menu. halaman input nilai adalah tampilan dimana dosen melakukan proses menginputkan data nilai mahasiswa. halaman form nilai adalah halaman yang menampilkan sebuah tabel informasi penilaian mahasiswa pkl yang dilakukan oleh dosen. Halaman yang menampilkan informasi daftar kegiatan mahasiswa selama pkl berlangsung.

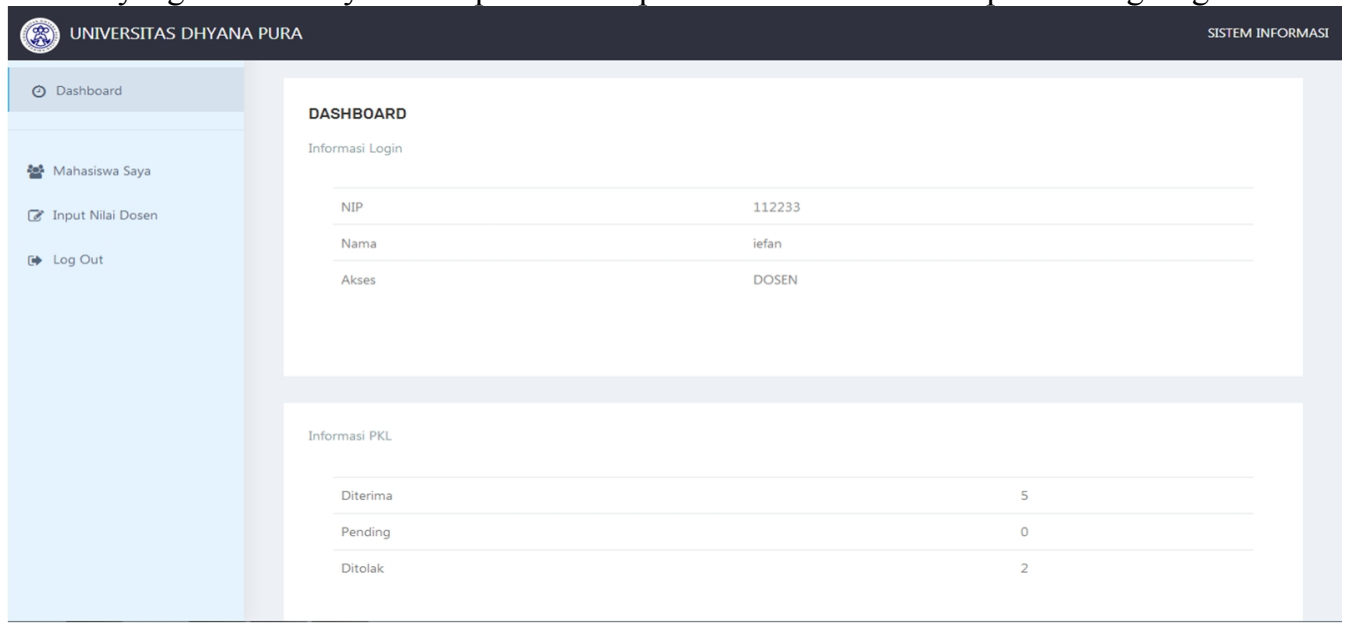

Gambar 4. Menu Utama Dosen 


\section{Implementasi Antar Muka Halaman Dashboard Mahasiswa}

Tampilan utama setelah login mahasiswa. Pada halaman dashboard mahasiswa akan tampil informasi login mahasiswa dan informasi pkl mahasiswa. Pada sisi kiri halaman terdapat beberapa menu pilihan. halaman PKL adalah halaman yang menampilkan sebuah informasi pkl mahasiswa dimana mahasiswa telah melakukan registrasi pkl terlebih dahulu. Halaman nilai menampilkan sebuah tabel informasi nilai pkl mahasiswa yang diperoleh dari dosen dan perusahaan. tampilan halaman kegiatan mahasiswa dimana halaman tersebut menampilkan informasi kegiatan mahasiswa selama pkl berlangsung. Dan terdapat beberapa button yang memiliki masing - masing proses yaitu Kembali, Tambah Kegiatan, Detail, dan Hapus. halaman tambah kegiatan adalah tampilan dimana mahasiswa melakukan proses tambah data kegiatan pkl mahasiswa pada tabel kegiata. Mahasiswa menginputkan data kegiatan dan tanggal kegiatan. Berkas halaman yang menampilkan informasi berkas pkl mahasiswa.

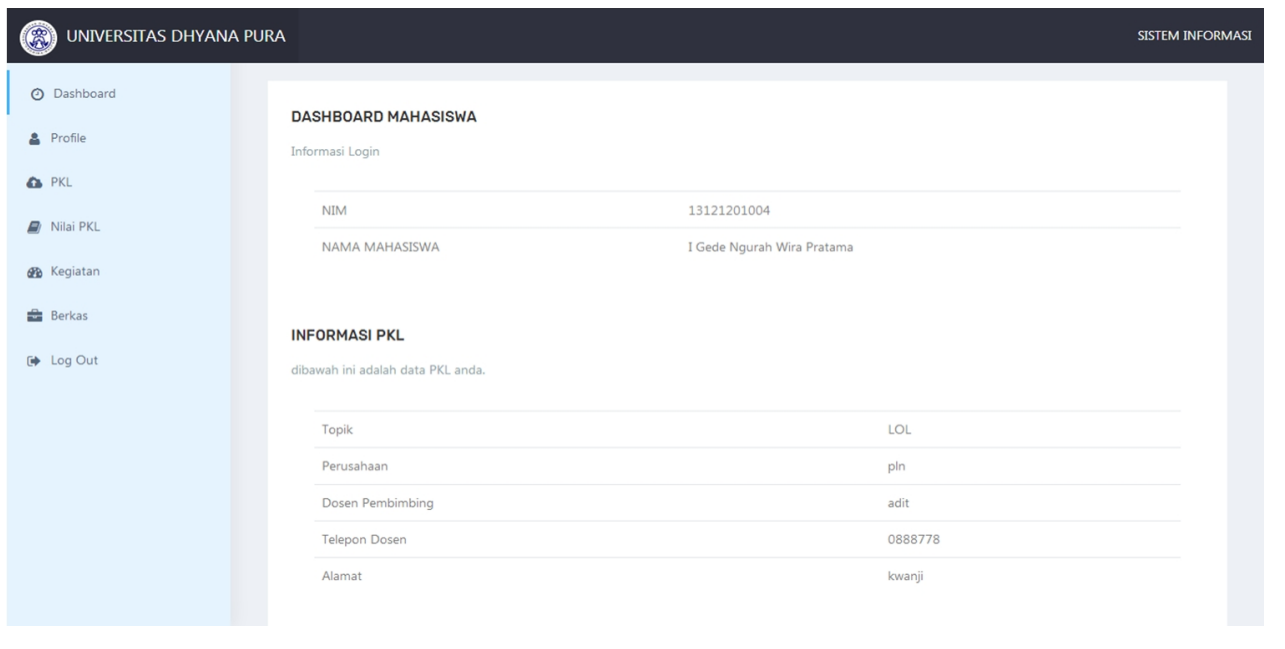

Gambar 5. Menu Utama Mahasiswa

\section{SIMPULAN}

Berdasarkan hasil perekayasaan ini adalah analisis, perancangan seperti DFD, ERD, dan konseptual database, implementasi Sistem Informasi Manajemen Praktek Kerja Lapangan Berbasis Website (Studi Kasus Program Studi Sistem Informasi Universitas Dhyana Pura Bali), adapun kesimpulan yang dapat diberikan adalah sebagai berikut :

Dapat mempermudah mahasiswa untuk mendapatkan informasi yang jelas, akurat, relevan dan benar tentang praktek kerja lapangan yang akan mereka lakukan. Menyajikan Sistem Informasi Praktek Kerja Lapangan Pada Jurusan Sistem Informasi Universitas Dhyana Pura Bali

\section{DAFTAR PUSTAKA}

1] Anhar. 2010. Panduan Menguasai PHP dan Mysql. Jakarta: Media Kita.
2] Buku Pedoman Praktek Kerja Lapangan Program Studi Sistem Informasi Universitas Dhyana Pura Bali

3] Jogiyanto. 2005. Analisis dan Desain Sistem Informasi. Yogyakarta: Penerbit Andi.

4] Ladjamudin, bin Albahra. 2005. Analisis dan Design Sistem Informasi. Yogyakarta: Graha Ilmu.

5] Madcoms. 2010. Kupas Tuntas Adobe Dreamweaver CS5 dengan Pemrograman PHP dan MySQL. Yogyakarta: Andi. 
6] Muhammad Arifin, 2014, Analisa dan Perancangan Sistem Informasi Praktek Kerja Lapangan Pada Instansi/Perusahaan, Jurnal SIMETRIS, Vol 5 No 1, ISSN: 22524983

7] Ryan Adiwinata, Eko Adi Sarwoko, Indriyati, 2011, Sistem Informasi Tugas Akhir dan PraktekKerja Lapangan Berbasis Web Menggunakan Metode Unified Process, Jurnal Masyarakat Informatika Volume 2 Nomor 3, ISSN 2086-4930
8] Teguh Andriyanto, Risky Aswi R, 2016, Rancang Bangun Sistem Informasi Praktek Kerja Lapangan Terintegrasi Menggunakan Webservice, Jurnal SIMETRIS, Vol 7 No 2, ISSN: 2252-4983

9] Tommy Agus, 2015, Perancangan Sistem Informasi Akademik Sekolah Berbasis Web (Studi Kasus SMPK Harapan Denpasasr), Jurnal Teknologi Informasi dan Komputer, Vol 1, NO 1, ISSN: 2442-241X 